\title{
PENGARUH PENGELUARAN PEMERINTAH TERHADAP PERTUMBUHAN EKONOMI DI PROVINSI JAMBI
}

\author{
M. Zahari $\mathrm{MS}^{1}$
}

\begin{abstract}
Positive economic growth indicates an increase in the economy of a country or region, whereas negative economic growth indicates a decline in the economy of a country or region. The indicator used to measure regional economic growth is the growth rate of Gross Regional Domestic Product at constant prices (real $G D P)$. In increasing the economic growth of a region, not apart from the role of government in providing funds to finance regional economic development activities. Costs incurred for public service activities and development both economic and non-economic are often referred to as government expenditures. These government expenditures are allocated annually in the Regional Revenue and Expenditure Budget. Excavation of potential sources of income to support local expenditure and regional independence needs to be intensified, especially those originating from local revenue sources optimally will be able to contribute significantly to the improvement of Jambi Province's Regional Income and Expenditure Budget. The purpose of this study is to determine the financial capacity of regions derived from local revenue in supporting the Regional Revenue and Expenditure Budget, and to determine the rate of regional economic growth and analyze the influence of regional spending on economic growth in Jambi Province. This research was conducted in the scope of government of Jambi Province. The research method used qualitative descriptive method and linear regression analysis of econometric model of Ordinary Least Square method (OLS). The results show that during the period from 2010 to 2016, the financial capacity of regions originating from local own revenues has not been fully reliable in sustaining the Jambi Provincial Revenue and Expenditure Budget, as its contribution is still relatively low at an average of 34.13 percent per year. The economic growth of Jambi Province during the same period grew by 6.28 percent per year. Government expenditures significantly and positively affect the Economic Growth of Jambi Province. The conclusion is that an increased regional government spending will lead to increased economic growth of the region concerned.

Keywords: Regional Finance, Government Expenditure, Economic Growth.
\end{abstract}

\section{PENDAHULUAN}

Pertumbuhan ekonomi merupakan salah satu indikator untuk melihat hasil pembangunan yang telah dilakukan dan juga berguna untuk menentukan arah pembangunan di masa yang akan datang. Pertumbuhan ekonomi yang positif menunjukkan adanya peningkatan perekonomian, sebaliknya pertumbuhan ekonomi negatif menunjukkan adanya penurunan dalam perekonomian. Pertumbuhan ekonomi menjadi tujuan bangsa agar dapat pula meningkatkan pembangunan nasional yang dapat meningkatkan kualitas manusia dan masyarakat Indonesia yang dilakukan secara berkelanjutan berdasarkan kemampuan nasional. Selain itu pertumbuhan ekonomi yang positif menjadi target utama bagi seluruh negara baik negara maju maupun negara berkembang, karena dengan

\footnotetext{
${ }^{1}$ Dosen Fakultas Ekonomi Universitas Batanghari
} 
pertumbuhan ekonomi yang positif maka akan semakin banyak investor yang tertarik untuk menanamkan modal di negara tersebut, sehingga dengan semakin banyak investor yang masuk maka ketersediaan modal juga akan semakin meningkat sehingga diharapkan dengan investasi yang semakin meningkat, maka akan semakin besar pula kesempatan kerja yang ditawaran. Dengan demikian angkatan kerja akan semakin banyak yang terserap, sehingga tingkat pengangguran akan dapat ditekan.

Indikator yang digunakan untuk mengukur pertumbuhan ekonomi daerah adalah tingkat pertumbuhan Produk Domestik Regional Bruto (PDRB). Nilai PDRB yang digunakan dalam mengukur pertumbuhan ekonomi dilihat dari nilai konstan. Ada beberapa alasan yang mendasari pemilihan pertumbuhan ekonomi menggunakan produk domestik regional bruto (PDRB), yaitu:

1. PDRB merupakan jumlah nilai tambah yang dihasilkan oleh seluruh aktivitas produksi didalam perekonomian. Hal ini berarti peningkatan PDRB juga mencerminkan peningkatan balas jasa kepada faktor-faktor produksi yang digunakan dalam aktivitas produksi tersebut.

2. Batas wilayah perhitungan PDRB adalah negara (perekonomian domestik).

3. PDRB merupakan salah satu indikator yang dapat dijadikan ukuran untuk menilai keberhasilan pembangunan suatu daerah, atau tercermin melalui pertumbuhan PDRB.

Pada dasarnya, pertumbuhan ekonomi merupakan suatu proses pertumbuhan output perkapita dalam jangka panjang. Hal ini, bahwa dalam jangka panjang, kesejahteraan tercermin pada peningkatan output perkapita yang sekaligus memberikan banyak alternatif dalam mengkonsumsi barang dan jasa, serta diikuti oleh daya beli masyarakat yang semakin meningkat.

Kuznets mendefinisikan pertumbuhan ekonomi adalah kenaikan jangka panjang dalam kemampuan suatu negara untuk menyediakan semakin banyak barang-barang ekonomi kepada penduduknya. Kemampuan ini tumbuh sesuai dengan kemajuan teknologi, penyesuaian kelembagaan, dan ideologi yang diperlukannya (Jhingan, 2002).

Menurut Sukirno (2013) pertumbuhan dan pembangunan ekonomi memiliki definisi yang berbeda, yaitu pertumbuhan ekonomi ialah proses kenaikan output perkapita yang terus menerus dalam jangka panjang. Pertumbuhan ekonomi tersebut merupakan salah satu indikator keberhasilan pembangunan. Dengan demikian makin tingginya pertumbuhan ekonomi biasanya makin tinggi pula kesejahteraan masyarakat, meskipun terdapat indikator yang lain yaitu distribusi pendapatan. Sedangkan pembangunan ekonomi ialah usaha meningkatkan pendapatan perkapita dengan jalan mengolah kekuatan ekonomi potensial menjadi ekonomi rill melalui penanaman modal, penggunaan teknologi, penambahan pengetahuan, peningkatan keterampilan, penambahan kemampuan berorganisasi dan manajemen. Ada empat faktor atau komponen utama dalam pertumbuhan ekonomi dari setiap bangsa yaitu

1) Tanah dan kekayaan alam lainnya (SDA),

2) Barang-barang modal dan tingkat teknologi yang mencakup semua investasi baru dalam lahan, peralatan fisik dengan kemajuan teknologi,

3) Jumlah dan mutu dari penduduk dan tenaga kerja melalui peningkatan kesehatan, pendidikan dan keterampilan kerja, pertumbuhan populasi yang akhirnya menyebabkan pertumbuhan angkatan kerja, 
4) Sistem sosial dan masyarakat menentukan sampai dimana pertumbuhan ekonomi dapat dicapai, seperti sikap berhemat yang bertujuan untuk melakukan investasi, sikap bekerja keras dsb. Hal ini sejalan dengan teori ekonomi neo klasik yang menitikberatkan pada modal dan tenaga kerja serta perubahan teknologi sebagai unsur baru.

Sementara itu dalam analisis makro dijelaskan bahwa tingkat pertumbuhan ekonomi yang dicapai oleh suatu negara diukur dari perkembangan pendapatan nasional riil yang dicapai. Terdapat 4 komponen pengeluaran agregat dalam perekonomian yaitu : konsumsi rumah tangga, pengeluaran pemerintah, pembentukan modal sektor swata (investasi), dan export netto (ekspor dikurangi impor).

Pengukuran dalam perekonomian di suatu negara adalah produk domestik bruto (PDB). PDB mengukur aliran pendapatan dan pengeluaran dalam perekonomian selama periode tertentu. Pertumbuhan ekonomi berkaitan dengan proses peningkatan produksi barang dan jasa dalam kegiatan ekonomi masyarakat. Untuk mengukur pertumbuhan ekonomi, nilai PDB berdasarkan harga konstan (PDB Rill) Sehingga angka pertumbuhan yang dihasilkan merupakan pertumbuhan rill yang terjadi karena adanya pertambahan produksi (Mankiw: 2007).

Salah satu indikator keberhasilan pelaksanaan pembangunan yang dapat dijadikan tolok ukur secara makro adalah pertumbuhan ekonomi, akan tetapi, meskipun telah digunakan sebagai indikator pembangunan, pertumbuhan ekonomi masih bersifat umum dan belum mencerminkan kemampuan masyarakat secara individual. Pembangunan daerah diharapkan akan membawa dampak positif pula terhadap pertumbuhan ekonomi. Pertumbuhan ekonomi daerah dapat dicerminkan dari perubahan PDRB dalam suatu wilayah (Suryono, 2010). Keberhasilan suatu daerah dalam meningkatkan kesejahteraan warganya diukur melalui tingkat pertumbuhan ekonomi yang berhasil dicapai. Tinggi rendah laju pertumbuhan ekonomi suatu daerah menunjukkan tingkat perubahan kesejahteraan ekonomi masyarakatnya. Pertumbuhan ekonomi yang tinggi dan stabil dari tahun ke tahun berarti kesejahteraan ekonomi meningkat, sementara perekonomian yang menurun atau pertumbuhan ekonomi dengan nilai negatif berarti turunnya kesejahteraan ekonomi. Disisi lain tingkat pertumbuhan ekonomi juga digunakan untuk mengevaluasi tepat atau tidaknya kebijakan yang telah diambil sehubungan dengan peran pemerintah dalam perekonomian.

Pertumbuhan ekonomi Provinsi Jambi pada tahun 2005-2015 masih tetap positif walaupun sifatnya fluktiatif. Selama kurun waktu 2005-2015 Provinsi Jambi memiliki laju pertumbuhan ekonomi tertinggi se-Sumatera dengan rata-rata laju pertumbuhan mencapai $6,63 \%$, dikuti oleh Provinsi Kepulauan Riau mengalami pertumbuhan ekonomi sebesar $6,59 \%$. Sedangkan yang paling rendah terjadi Provinsi Aceh yaitu - 0,09\% dan terendah kedua Provinsi Riau sebesar $3,93 \%$ rata-rata pertahun. 
Tabel 1

Laju Pertumbuhan Ekonomi menurut Provinsi se-Sumatera Tahun 2005-2015 (Dalam Persen)

\begin{tabular}{lcccccccccccc}
\hline Provinsi & $\mathbf{2 0 0 5}$ & $\mathbf{2 0 0 6}$ & $\mathbf{2 0 0 7}$ & $\mathbf{2 0 0 8}$ & $\mathbf{2 0 0 9}$ & $\mathbf{2 0 1 0}$ & $\mathbf{2 0 1 1}$ & $\mathbf{2 0 1 2}$ & $\mathbf{2 0 1 3}$ & $\mathbf{2 0 1 4}$ & $\mathbf{2 0 1 5}$ & Rerata \\
\hline Aceh & -10.12 & 1.56 & -2.36 & -5.24 & -5.51 & 2.74 & 4.84 & 5.14 & 4.18 & 1.65 & 2.14 & -0.09 \\
Sumut & 5.48 & 6.2 & 6.9 & 6.39 & 5.07 & 6.42 & 6.63 & 6.22 & 6.01 & 5.23 & 5.33 & 5.99 \\
Sumbar & 5.73 & 6.14 & 6.34 & 6.88 & 4.28 & 5.94 & 6.26 & 6.38 & 6.18 & 5.85 & 5.62 & 5.96 \\
Riau & 5.41 & 5.15 & 3.41 & 5.65 & 2.97 & 4.21 & 5.04 & 3.54 & 2.61 & 2.62 & 2.66 & 3.93 \\
Jambi & 5.57 & 5.89 & 6.82 & 7.16 & 6.39 & 7.76 & 7.86 & 7.03 & 6.84 & 7.35 & 4.21 & 6.63 \\
Sumsel & 4.84 & 5.2 & 5.84 & 5.07 & 4.11 & 5.63 & 6.5 & 6.01 & 5.98 & 4.68 & 4.57 & 5.31 \\
Bengkulu & 5.82 & 5.95 & 6.46 & 5.75 & 5.62 & 6.1 & 6.46 & 6.6 & 6.21 & 5.49 & 5.41 & 5.99 \\
Lampung & 4.02 & 4.98 & 5.94 & 5.35 & 5.26 & 5.88 & 6.43 & 6.53 & 5.97 & 5.08 & 4.9 & 5.49 \\
Babel & 3.47 & 3.98 & 4.54 & 4.6 & 3.74 & 5.99 & 6.5 & 5.73 & 5.29 & 4.68 & 4.76 & 4.84 \\
Kep.Riau & 6.57 & 6.78 & 7.01 & 6.63 & 3.52 & 7.19 & 6.66 & 6.82 & 6.13 & 7.32 & 7.89 & 6.59 \\
Sumatera & $\mathbf{3 . 6 8}$ & $\mathbf{5 . 1 8}$ & $\mathbf{5 . 0 9}$ & $\mathbf{4 . 8 2}$ & $\mathbf{3 . 5 5}$ & $\mathbf{5 . 7 9}$ & $\mathbf{6 . 3 2}$ & $\mathbf{6 . 0 0}$ & $\mathbf{5 . 5 4}$ & $\mathbf{5 . 0 0}$ & $\mathbf{4 . 7 5}$ & $\mathbf{5 . 0 6}$ \\
\hline
\end{tabular}

Sumber: BPS Nasional 2005-2015, diolah

Pertumbhan ekonomi sebagai tolak ukur suatu daerah, juga tidak terlepas dari peran pemerintah dalam menyediakan dana untuk membiaya kegiatan pembangunan baik bidang ekonomi maupun non ekonomi. Biaya kegiatan ini sering disebut sebagai pengeluaran pemerintah. Pengeluaran pemerintah daerah diukur dari total belanja langsung dan belanja tidak langsung yang dialokasikan dalam anggaran daerah. Sodik (2007), mengungkapkan bahwa pengeluaran pemerintah yang proposional akan meningkatkan pertumbuhan ekonomi. Hubungan antara pertumbuhan ekonomi dan pengeluaran pemerintah menjadi subjek penting untuk dianalisis. Secara umum gambaran pengeluaran publik, yaitu infrastuktur fisik atau human capital, dapat mempertinggi pertumbuhan tetapi pengeluaran dapat pula memperlambat pertumbuhan perekonomian suatu daerah.

Dalam perekonomian modern, Pemerintah sebagai pelaku ekonomi memiliki peranan penting dalam mengatur, mengawasi perekonomian, pemerintah juga mampu melaksanakan kegiatan ekonomi yang tidak dapat dilaksanakan oleh pelaku ekonomi lainnya baik swasta maupun rumah tangga (Hidayat, 2010). Untuk itulah diperlukan campur tangan pemerintah dibutuhkan dalam satu perekonomian dan hanya untuk kegiatan yang menyangkut hajat hidup orang banyak.

Kebijakan pengeluaran pemerintah yang secara langsung dapat mendorong pertumbuhan ekonomi adalah belanja karena variabel ini diwujudkan pembangunan prasarana ekonomi dan sosial. Perkembangan pengeluaran pemerintah yang diukur dari besarnya belanja langsung dan belanja tidak langsung. Pengklasifikasian belanja langsung dan tidak langsung ini digunakan dalam sistem penganggaran pemerintah baik pusat maupun daerah, yaitu sejak penerapan PP No. 105 Tahun 2000 tentang Pertanggungjawaban Pengelolaan Keuangan Daerah dan Kepmendagri No. 29 Tahun 2002 yang kemudian direvisi menjadi PP No. 58 Tahun 2008 tentang Pengelolaan Keuangan Daerah dan Permendagri No. 59 Tahun 2007 sebagai revisi Permendagri No. 13 Tahun 2006 tentang Pedoman Pengelolaan Keuangan Daerah.

Dalam peraturan yang lama sebagaimana diatur dalam Kepmendagri No. 29 Tahun 2002, belanja daerah diklasifikasikan menjadi belanja administrasi umum, 
belanja operasi dan pemeliharaan, belanja modal, belanja tidak tersangka, dan belanja bantuan keuangan. Kemudian, beradasarkan PP No. 58 Tahun 2008 dan Permendagri No. 59 Tahun 2007, klasifikasi belanja dalam sistem anggaran diperbaiki menjadi Belanja Tidak Langsung dan Belanja Langsung.

Perkembangan belanja Daerah Provinsi Jambi, selama periode 2010 - 2016 dapat dilihat pada tabel berikut:

Tabel 2

Realisasi Belanja Daerah Provinsi Jambi Tahun 2010 - 2016 (Juta Rupiah)

\begin{tabular}{cccccccc}
\hline Tahun & $\begin{array}{c}\text { Belanja } \\
\text { Tidak } \\
\text { Langsung } \\
(\text { BTL) }\end{array}$ & $\begin{array}{c}\text { Belanja } \\
\text { Langsung } \\
(\mathbf{B L})\end{array}$ & $\begin{array}{c}\text { Pembiayaan } \\
(\text { PyD) }\end{array}$ & $\begin{array}{c}\text { TOTAL } \\
\text { BELANJA }\end{array}$ & BTL & BL & PyD \\
\hline 2010 & 672,277 & 815,863 & 353,260 & $1,841,400$ & 36.51 & 44.31 & 19.18 \\
2011 & 760,339 & 989,902 & 70,923 & $1,821,164$ & 41.75 & 54.36 & 3.89 \\
2012 & $1,245,496$ & $1,286,101$ & 56,425 & $2,588,022$ & 48.13 & 49.69 & 2.18 \\
2013 & $1,271,926$ & $1,738,815$ & 566,331 & $3,577,072$ & 35.56 & 48.61 & 15.83 \\
2014 & $1,483,116$ & $1,721,517$ & 474,526 & $3,679,159$ & 40.31 & 46.79 & 12.90 \\
2015 & $1,762,391$ & $1,663,175$ & 178,679 & $3,604,245$ & 48.90 & 46.14 & 4.96 \\
$2016 *)$ & $1,738,499$ & $2,003,525$ & - & $3,742,024$ & 46.46 & 53.54 & 0.00 \\
\hline
\end{tabular}

Sumber: BPS Provinsi Jambi, diolah

Berdasarkan tabel 2, diketahui realisasi belanja pemerintah daerah Provinsi Jambi cenderung mengalami peningkatan. Pada awal tahun 2010, pengeluaran pemerintah sebesar Rp. 1,84 triliun, kemudian di tahun 2016 meningkat menjadi Rp. 3,74 triliun. Porsi belanja lansung lebih besar dibandingkan belanja tidak langsung dan cenderung meningkat, dimana belanja lansung pada tahun 2010 sebesar 44,31\% dan pada tahun 2016 menjadi 53,54\%, sedangkan belanja tidak langsung porsinya pada tahun 2010 sebesar 36,51\% dan pada tahun 2016 menjadi $44,46 \%$.

Gambaran ini, menunjukkan perlu adanya kerja keras segenap aparatur Pemerintah Daerah Provinsi Jambi untuk berupaya meningkatkan kemampuan keuangan daerah, terutama penyediaan dana yang bersumber dari Pendapatan Asli Daerah (PAD). Pada APBD murni Provinsi Jambi tahun 2017, Pendapatan Daerah ditargetkan sejumlah Rp. 4.163 miliar, terdiri atas PAD sejumlah Rp.1.393 miliar (33,46\%), Dana Perimbangan sejumlah Rp.2.766 miliar (66,44\%), dan Lain-lain Pendapatan Daerah yang Sah sejumlah Rp 0,5 miliar, sedangkan alokasi Belanja Daerah dianggarkan sejumlah Rp.4.342 miliar, terdiri dari Belanja Tidak Langsung sejumlah Rp.2.366 miliar (54,49\%) dan Belanja Langsung sebesar Rp 1.975 miliar (45,49\%). Sisa Lebih Perhitungan Anggaran (SiLPA) Tahun 2016 diprediksi Rp 178,5 miliar untuk menutupi defisit anggaran tahun 2017 tersebut.

Mengingat kondisi dan potensi yang berbeda-beda antara masing-masing daerah membawa konsekuensi adanya perbedaan kemampuan dalam menggerakkan kegiatan pembangunan dan pelayanan publik sehingga dapat menimbulkan berbagai persoalan, terutama menyangkut masalah pengelolaan sumber-sumber potensi daerah, guna meningkatkan pertumbuhan ekonomi daerah. Dalam kesempatan ini penulis, berkeinginan untuk mengkaji lebih lanjut tentang 
pengeluaran pemerintah daerah yang dikaitkan dengan pertumbuhan ekonomi daerah di Provinsi Jambi.

Adapun rumusan masalah dalam penelitian ini adalah : 1) Bagaimana kemampuan keuangan daerah di Provinsi Jambi? 2) Bagaimana laju pertumbuhan ekonomi daerah di Provinsi Jambi? 3) Bagaimana pengaruh belanja daerah terhadap pertumbuhan ekonomi di Provinsi Jambi?

Tujuan dari penelitian ini adalah : 1) Mengetahui kemampuan keuangan daerah di Provinsi Jambi. 2) Mengetahui laju pertumbuhan ekonomi daerah di Provinsi Jambi. 3) Menganalisis pengaruh belanja daerah terhadap pertumbuhan ekonomi daerah di Provinsi Jambi.

Dalam penelitian ini, adapun output yang diharapkan atau manfaat dari penelitian ini adalah: 1) Sebagai bahan masukan bagi pemerintah dalam mengambil keputusan khususnya yang berkaitan dengan pengeluaran pemerintah daerah yang digunakan untuk mengejar pertumbuhan ekonomi daerah yang lebih baik. 2) Hasil penelitian ini dapat dijadikan referensi dan perbandingan dalam meneliti terhadap objek penelitian yang sama khususnya tentang Pengaruh Pengeluaran Pemerintah Daerah terhadap Pertumbuhan Ekonomi di Provinsi Jambi.

\section{Pertumbuhan Ekonomi}

\section{TINJAUAN PUSTAKA}

Secara umum, pertumbuhan ekonomi menunjukkan aktivitas perekonomian suatu Negara atau daerah dalam menghasilkan tambahan pendapatan masyarakat pada suatu periode tertentu. Menurut Sukirno (2013) pertumbuhan ekonomi diartikan sebagai perkembangan kegiatan dalam perekonomian yang menyebabkan barang dan jasa yang diproduksi dalam masyarakat bertambah dan kemakmuran masyarakat meningkat. Menurut Prasetyo (2009), istilah pertumbuhan ekonomi (economic growth) secara paling sederhana dapat diartikan sebagai pertambahan output atau pertambahan pendapatan nasional agregat dalam kurun waktu tertentu misalkan satu tahun. Perekonomian suatu negara dikatakan mengalami pertumbuhan jika jumlah balas jasa riil terhadap penggunaan faktor-faktor produksi pada tahun tertentu lebih besar daripada tahun-tahun sebelumnya.

Menurut Simon Kuznets dalam M.L Jhingan (2002) pertumbuhan ekonomi adalah peningkatan kemampuan suatu negara (daerah) untuk menyediakan barang-barang ekonomi bagi penduduknya, yang terwujud dengan adanya kenaikan output nasional secara terus-menerus yang disertai dengan kemajuan teknologi serta adanya penyesuaian kelembagaan, sikap dan ideologi yang dibutuhkannya. Hampir senada dengan Simon Kuznets, menurut Todaro dan Smith (2006) pertumbuhan ekonomi merupakan suatu proses peningkatan kapasitas produktif dalam suatu perekonomian secara terus menerus atau berkesinambungan sepanjang waktu sehingga menghasilkan tingkat pendapatan dan output nasional yang semakin lama semakin besar.

Menurut pandangan ekonom klasik, Adam Smith, David Ricardo, Thomas Robert Malthus dan John Straurt Mill, maupun ekonom neo klasik, Robert Solow dan Trevor Swan, mengemukakan bahwa pada dasarnya ada empat faktor yang mempengaruhi pertumbuhan ekonomi yaitu (1) jumlah penduduk, (2) jumlah stok barang modal, (3) luas tanah dan kekayaan alam, dan (4) tingkat teknologi yang digunakan. 
Kuznets (dalam Todaro, 2000), mengemukakan ada enam karakteristik atau ciri proses pertumbuhan ekonomi sebagai berikut:

a. Tingkat pertambahan output perkapita dan pertambahan penduduk yang tinggi.

b. Tingkat kenaikan total produktivitas faktor yang tinggi, khususnya produktivitas tenaga kerja.

c. Tingkat transformasi struktural ekonomi yang tinggi.

d. Tingkat transformasi sosial dan ideologi yang tinggi.

e. Adanya kecenderungan daerah yang mulai atau sudah maju perekonomiannya untuk berusaha menambah bagian-bagian daerah lainnya sebagai daerah pemasaran dan sumber bahan baku.

f. Terbatasnya penyebaran pertumbuhan ekonomi yang hanya mencapai sepertiga bagian penduduk dunia.

Pertumbuhan ekonomi yang tinggi dan prosesnya yang berkelanjutan merupakan kondisi utama bagi kelangsungan pembangunan ekonomi (Tambunan, 2001). Pertumbuhan ekonomi menunjukkan sejauh mana aktivitas perekonomian akan menghasilkan tambahan pendapatan masyarakat pada suatu periode tertentu. Dengan kata lain, perekonomian dikatakan mengalami pertumbuhan bila pendapatan riil masyarakat pada tahun tertentu lebih besar dari pada pendapatan riil masyarakat pada tahun sebelumnya.

Pertumbuhan ekonomi merupakan faktor terpenting dalam pembangunan. Keberhasilan pembangunan suatu negara/wilayah diukur berdasarkan tinggi rendahnya tingkat pertumbuhan ekonomi yang dicapai. Pengukuran pertumbuhan ekonomi secara konvensional biasanya dengan menghitung peningkatan persentase dari Produk Domestik Bruto (PDB) untuk nasional dan Produk Domestik Regional Bruto (PDRB) untuk provinsi maupun kabupaten/kota. PDRB merupakan jumlah nilai tambah yang dihasilkan oleh seluruh unit usaha dalam suatu wilayah tertentu atau merupakan jumlah nilai barang dan jasa akhir yang dihasilkan oleh seluruh unit ekonomi selama periode tertentu. Oleh karena itu, pertumbuhan ekonomi suatu wilayah dapat diperoleh melalui tingkat pertumbuhan nilai PDRB Atas Dasar Harga Konstan (ADHK).

Pertumbuhan ekonomi suatu daerah dapat diketahui dengan membandingkan PDRB Riil pada satu tahun tertentu (PDRBt) dengan PDRB tahun sebelumnya (PDRB t-1)

Laju Pertumbuhan Ekonomi $=\frac{P D R B \mathrm{t}-P D R B_{\mathrm{t}-1}}{P D R B \mathrm{t}-1} \times 100 \%$

\section{Pengeluaran Daerah}

Pengeluaran daerah diperoleh dari seluruh pendapatan daerah yang diterima baik dari daerahnya sendiri maupun bantuan dari pemerintah pusat yang akan digunakan untuk membiayai seluruh kegiatan daerah.

Menurut UU No. 23 Tahun 2014 tentang Pemerintah Daerah, belanja daerah adalah semua kewajiban daerah yang diakui sebagai pengurang nilai kekayaan bersih dalam periode anggaran yang bersangkutan. Belanja daerah sebagaimana dimaksud dalam Peraturan Menteri Dalam Negeri Nomor 52 Tahun 2015 tentang Pedoman Pengelolaan Keuangan Daerah, menyebutkan bahwa belanja daerah dipergunakan dalam rangka mendanai pelaksanaan urusan pemerintah yang menjadi kewenangan provinsi atau kabupeten/kota yang terdiri dari urusan wajib, urusan pilihan dan urusan yang penanganannya 
dalam bagian atau bidang tertentu yang dapat dilaksanakan bersama antara pemerintah dan pemerintah daerah atau antar pemerintah daerah yang ditetapkan berdasarkan peraturan perundang-undangan.

Belanja diklasifikasikan berdasarkan hubungannya dengan aktivitas, sehingga belanja dikelompokkan menjadi 2 bagian.

a. Belanja tidak langsung adalah bagian belanja yang dianggarkan tidak terkait langsung dengan pelaksanan program dan kegiatan. Seperti belanja pegawai berupa gaji dan tunjangan yang telah di tetapkan oleh undang-undang, belanja bunga, belanja hibah, belanja bantuan social, belanja bagi hasil kepada provinsi/kabupaten/kota dan pemerintah dasa, belanja bantuan keuangan dan belanja tak tersangka.

b. Belanja langsung adalah belanja yang dianggarkan yang terkait secara langsung dengan pelaksanaan program dan kegiatan. Seperti belanja pegawai, belanja barang dan jasa, serta belanja modal untuk melaksanakan program dan kegiatan pemerintah daerah dan telah dianggarkan oleh pemerintah daerah.

Versi Keynes, pengeluaran pemerintah merupakan salah satu unsur permintaan agregat. Konsep perhitungan pendapatan nasional dengan pendekatan pengeluaran bahwa $\mathrm{Y}=\mathrm{C}+\mathrm{I}+\mathrm{G}+\mathrm{X}-\mathrm{M}$. Formula ini dikenal sebagai identitas pendapatan nasional. Variabel $\mathrm{Y}$ melambangkan pendapatan nasional sekaligus mencerminkan penawaran agregat. Variabel-variabel di ruas kanan disebut permintaan agregat. Variabel $G$ melambangkan pengeluaran pemerintah. Dengan membandingkan nilai G terhadap Y serta mengamati dari waktu ke waktu dapat diketahui seberapa besar kontribusi pengeluaran pemerintah dalam pembentukan pendapatan nasional (Dumairy, 1996)

Teori pembangunan dan pengeluaran pemerintah dikembangkan oleh Rostow dan Musgrave yang menghubungkan pengeluaran pemerintah dengan tahap-tahap pembangunan ekonomi yang dibedakan antara tahap awal, tahap menengah dan tahap lanjut. (1) Tahap awal, pada tahap awal perkembangan ekonomi persentase investasi besar, sebab pemerintah harus menyediakan prasarana, seperti pendidikan, kesehatan, prasarana transportasi dan sebagainya. (2) Tahap menengah, investasi pemerintah tetap diperlukan untuk meningkatkan pertumbuhan ekonomi agar dapat tinggal landas, namun peranan investasi swasta sudah semakin membesar. (3) Tahap lanjut, pembangunan ekonomi dan aktivitas pemerintah beralih dari penyediaan prasarana ke pengeluaran-pengeluaran untuk aktivitas sosial seperti program kesejahteraan hari tua dan program pelayanan kesehatan masyarakat (Mangkoesoebroto, 2008).

\section{Hubungan Pengeluaran Pemerintah dengan Pertumbuhan Ekonomi}

Pengeluaran pemerintah (goverment expenditure) adalah bagian dari kebijakan fiskal yakni suatu tindakan pemerintah untuk mengatur jalannya perekonomian dengan cara menentukan besarnya penerimaan dan pengeluaran pemerintah tiap tahunnya yang tercermin dalam dokumen APBN untuk nasional dan APBD untuk daerah/regional. Tujuan dari kebijakan fiskal ini adalah dalam rangka menstabilkan harga, tingkat output maupun kesempatan kerja dan memacu pertumbuhan ekonomi (Sukirno, 2008).

Teori Peacock dan Wiseman menyebutkan bahwa perkembangan ekonomi menyebabkan pemungutan pajak yang semakin meningkat walaupn tarif pajak tidak berubah; dan meningkatnya penerimaan pajak menyebabkan 
pengeluaran pemerintah juga semakin meningkat. Oleh karena itu, dalam keadaan normal, meningkatnya GDP menyebabkan penerimaan pemerintah yang semakin besar, begitu juga dengan pengeluaran pemerintah menjadi semakin besar. Maka pengeluaran pemerintah yang diklasifikasikan menjadi belanja langsung dan belanja tidak langsung jika meningkat maka menyebabkan GNP (dalam penelitian ini adalah output) meningkat pula.

Teori Peacock dan Wiseman mengenai pengeluaran pemerintah sering disebut sebagai The Displacement Effect, dimana teori ini didasarkan pada suatu pandangan bahwa pemerintah senantiasa memperbesar pengeluaran, sedangkan masyarakat tidak suka membayar pajak yang semakin besar untuk membiayai pengeluaran pemerintah yang semakin besar tersebut. Peacock dan Wiseman mendasarkan teori mereka pada suatu teori bahwa masyarakat mempunyai suatu tingkat toleransi pajak, suatu tingkat dimana masyarakat dapatmemahami besarnya pungutan pajak yang dibutuhkan oleh pemerintah untukmembiayai pengeluaran pemerintah. Tingkat toleransi ini merupakan kendala bagi pemerintah untuk menaikkan pungutan pajak.

Dalam teori Peacock dan Wiseman, dinyatakan juga bahwa pertumbuhan ekonomi menyebabkan pemungutan pajak semakin meningkat walaupun tarif pajak tidak berubah, dan meningkatnya penerimaan pajak menyebabkan pengeluaran pemerintah juga semakin meningkat. Peningkatan pada PDB dalam keadaan normal menyebabkan penerimaan penerimaan pemerintah yang semakin besar, begitu juga dengan pengeluaran pemerintah. Apabila keadaan normal tersebut terganggu, misalnya karena adanya perang, maka pemerintah harus memperbesar pengeluarannya untuk membiayai perang. Salah satu cara umtuk meningkatkan penerimaannya tersebut dengan menaikkan tarif pajak sehingga dana swasta untuk investasi dan konsumsi menjadi berkurang. Keadaan ini disebut efek pengalihan (Displacement effect) yaitu adanya gangguan sosial menyebabkan aktivitas swasta dialihkan pada aktivitas pemerintah.

Bird mengkritik hipotesa yang dikemukakan oleh Peacock dan Wiseman. Bird menyatakan bahwa selama terjadinya gangguan social memang terjadi pengalihan aktivitas pemerintah dari pengeluaran sebelum gangguan ke pengeluaran yang berhubungan dengan gangguan tersebut. Hal ini akan diikuti oleh peningkatan persentase pengeluaran pemerintah terhadap PDB. Akan tetapi setelah terjadinya gangguan, persentase pengeluaran pemerintah terhadap PDB akan menurun secara perlahan-lahan kembali ke keadaan semula. Jadi menurut Bird, efek pengalihan merupakangejala dalam jangka pendek, tetapi tidak terjadi dalam jangka panjang (Mangkoesoebroto, 2008).

\section{Hipotesis}

a. Kemampuan keuangan daerah di Provinsi Jambi relative rendah

b. Laju pertumbuhan ekonomi daerah di Provinsi Jambi

c. Pengeluaran pemerintah berpengaruh signifikan terhadap pertumbuhan ekonomi Provinsi Jambi.

\section{Jenis Data dan Sumber Data}

\section{METODE PENELITIAN}

Jenis data yang digunakan dalam penelitian data sekunder, yaitu data yang diperoleh dari instansi terkait yang ada hubunganya dengan penelitian ini. Data dan informasi yang dikumpulkan adalah data time series periode 7 tahun 
terakhir (2010 - 2016). Sumber data diperoleh dari instansi terkait seperti Badan Pusat Statistik (BPS), Bappeda, Biro Keuangan Provinsi Jambi.

\section{Motode Analisis Data}

\section{a. Analisis Deskriptif}

Dalam penelitian ini analisis dekskriptif digunakan untuk mengalisis kemampuan keuangan daerah dan pertumbuhan ekonomi. Analisis kemampuan keuangan daerah adalah pengkajian terhadap aspek-aspek penerimaan daerah baik yang berasal dari PAD maupun bantuan dari pemerintah pusat untuk mengetahui peranannya masing-masing terhadap APBD. Semakin tinggi peran PAD terhadap APBD menunjukkan semakin tinggi kemandirian keuangan daerah. Klasifikasi tingkat kemandirian tersebut sebagai berikut:

\section{Tabel 3}

Kemampuan Keuangan Daerah, Tingkat Kemandirian, dan Pola Hubungan

\begin{tabular}{ccc}
\hline Kemampuan Keu.Daerah & Kemandirian & Pola Hubungan \\
\hline Rendah Sekali & $0 \%-25 \%$ & Instruktif \\
Rendah & $25 \%-50 \%$ & Konsultatif \\
Sedang & $50 \%-75 \%$ & Partisipatif \\
Tinggi & $75 \%-100 \%$ & Delegatif \\
\hline
\end{tabular}

Sumber : Hersey dan Blanchard dalam Halim 2004.

Analisis pertumbuhan ekonomi adalah untuk mengkaji terhadap perkembangan ekonomi daerah yang dilihat dari PDRB atas harga konstan (PDRB riil).

Laju Pertumbuhan Ekonomi $=\frac{P D R B_{\mathrm{t}}-P D R B_{\mathrm{t}-1}}{P D R B_{\mathrm{t}-1}} \times 100 \%$

Dimana :

PDRBt $=$ PDRB Riil pada tahun $\mathrm{t}$

PDRB $_{\mathrm{t}-1}=$ PDRB Riil tahun sebelumnya

\section{b. Analisis Regresi Linier}

Metode analisis data yang digunakan dalam melihat besarnya pengaruh variabel independen terhadap variabel dependen digunakan analisis regresi linier model ekonomitrika metode Ordinary Least Square (OLS). Sebelum dilakukan analisis regresi linier terlebih dahulu dilakukan pengolahan data dengan menggunakan bantuan program SPSS versi 22.0.

Persamaan regresi linier model ekonomitrika adalah:

$\mathrm{Yt}=\alpha+\beta \mathrm{Xt}+\mathrm{e}$

Persamaan tersebut kemudian diformulasikan dalam bentuk logaritma natural (Ln) yang disesuaikan dengan variabel penelitian, menjadi :

$\operatorname{Ln} \mathrm{PE}_{\mathrm{t}}=\operatorname{Ln} \alpha+\operatorname{Ln} \beta \mathrm{TBD}_{\mathrm{t}}+\mathrm{e}$

Dimana :

PE = Pertumbuhan Ekonomi (PDRB atas harga konstan)

TBD = Pengeluaran Pemerintah (Total Belanja Darah)

Ln = Logaritma Natural

$\alpha \quad=$ Konstanta

$\beta \quad=$ Koefisien Regresi 
$\mathrm{t}=$ Periode waktu

$\mathrm{e}=$ Error

c. Koefisien Determinasi $\left(R^{2}\right)$

Uji determinasi (Uji $\mathrm{R}^{2}$ ) merupakan suatu ukuran yang penting dalam regresi, karena dapat menginformasikan baik atau tidaknya model regresi yang terestimasi, atau dengan kata lain angka tersebut dapat mengukur kedekatan garis regresi yang terestimasi dengan data sesungguhnya. Nilai koefisien determinasi $\left(\mathrm{R}^{2}\right)$ ini mencerminkan besaran variasi dari variabel terikat $\mathrm{Y}$ dapat diterangkan oleh variabel bebas $\mathrm{X}$. Bila nilai koefisien determinasi sama dengan $0\left(\mathrm{R}^{2}=0\right)$, artinya variasi dari $\mathrm{Y}$ tidak dapat diterangkan oleh $\mathrm{X}$ sama sekali. Nilai $\mathrm{R}^{2}=1$, artinya variasi dari $\mathrm{Y}$ secara keseluruhan dapat diterangkan oleh $\mathrm{X}$. Dengan kata lain jika $\mathrm{R}^{2}=1$, maka semua titik pengamatan berada tepat pada garis regresi. Dengan demikian, baik atau buruknya suatu persamaan regresi ditentukan oleh $\mathrm{R}^{2}$ nya yang mempunyai nilai antara 0 (nol) dan 1 (satu). berikut:

Rumus koefisien determinasi $\left(\mathrm{R}^{2}\right)$, menurut Widarjono (2005), sebagai

$$
\begin{array}{r}
\mathrm{b}(\square \mathrm{XY}) \\
\mathrm{R}^{2}=\square \square \square \square \square \\
\square \mathrm{Y}^{2}
\end{array}
$$

dimana:

$\mathrm{R}^{2}=$ Koefisien determinasi

$\mathrm{X}=$ Variabel bebas

$\mathrm{b}=$ Koefisien regresi

$\mathrm{Y}=$ Variabel terikat

Menurut Ghozali, (2011) apabila variabel independen pada penelitian lebih dari 2 (dua), maka koefisien determinasi yang digunakan adalah Adjusted $R$ Squre. Dalam penelitian ini penulis menggunakan koefisien determinasi ( $R^{2}$ ), karena variabel independen hanya ada satu, yaitu pengeluaran pemerintah (belanja daerah). Koefisien determinasi $\left(R^{2}\right)$ ini dapat menggambarkan suatu nilai yang menunjukkan besarnya variasi dari variabel $\mathrm{X}$ terhadap variasi naik turunnya variabel $\mathrm{Y}$ yang biasanya dinyatakan dalam persentase.

\section{Pengujian Hipotesis}

Uji t merupakan suatu pengujian yang bertujuan mengetahui apakah koefisien regresi suatu variabel independen signifikan atau tidak terhadap variabel dependen dengan menganggap independen lainnya konstan (Ceteris Paribus).

Rumus:

$$
\begin{aligned}
& \beta_{1}-\beta_{1}^{*} \\
& \mathrm{t}=\square \square \square \square \square \mathrm{t} \text { (n-k-1) } \\
& \text { se }\left(\beta_{1}\right)
\end{aligned}
$$


$\mathrm{n} \quad=$ jumlah data

$\mathrm{k}=$ jumlah variabel bebas

Nilai $\mathrm{t}$ di hitung selanjutnya dibandingkan dengan nilai $\mathrm{t}$ tabel pada derajat kebebasan (df) dengan tingkat keyakinan 95 persen atau taraf signifikan sebesar $\alpha=5 \%(0,05)$ akan dapat diperoleh hasil dengan kategori sebagai berikut:

$\mathrm{t}$ hitung $>\mathrm{t}$ tabel, maka Ho di tolak dan menerima Ha, artinya vartiabel $\mathrm{X}$ berpengaruh signifikan terhadap variabel Y.

$\mathrm{t}$ hitung $<\mathrm{t}$ tabel, maka Ho diterima dan menolak Ha, artinya vartiabel $\mathrm{X}$ tidak berpengaruh signifikan terhadap variabel Y.

\section{Kemampuan Keuangan Daerah}

\section{HASIL DAN PEMBAHASAN}

Sesuai dengan prinsip kesatuan bahwa pemerintah daerah merupakan yang tidak terpisahkan dari pemerintah pusat, atas dasar tersebut maka kemandirian daerah dalam rumah tangganya tidak ditafsirkan bahwa setiap pemerintah daerah harus dapat membiayai seluruh pengeluaran dari kemampuan keuangan daerahnya, sebagai tindak lanjut dari pemberian otonomi kepada daerah agar dapat mengatur dan mengurus rumah tangganya sendiri dalam meningkatkan daya guna dan hasil guna dalam pelaksanaan pemerintah di daerah maka upaya untuk meningkatkan kemampuan keuangan daerah melalui Pendapatan Asli Daerah adalah mutlak diperlukan untuk menunjang pembelanjaan pemerintah daerah dalam pelaksanaan pelayanan publik yang nyata dan bertanggung jawab.

Kemampuan keuangan darah yang tergambar dari kontribusi PAD terhadap APBD Provinsi Jambi pada tahun 2010 - 2016 , dapat dilihat pada tabel berikut:

Tabel 4

Kontribusi PAD terhadap APBD Provinsi Jambi Tahnu 2010-2016 (Miliar Rupiah)

\begin{tabular}{ccccc}
\hline TAHUN & PAD & $\begin{array}{c}\text { Dana } \\
\text { Perimbangan }\end{array}$ & APBD & $\begin{array}{c}\text { Rasio (\%) } \\
\text { PAD/APBD }\end{array}$ \\
\hline 2010 & 686 & 932 & 1.841 & 37,26 \\
2011 & 984 & 1.075 & 2.432 & 40,46 \\
2012 & 995 & 1.332 & 3.287 & 30,27 \\
2013 & 1.063 & 1.489 & 3.577 & 29,72 \\
2014 & 1.281 & 1.514 & 3.679 & 34,82 \\
2015 & 1.241 & 1.419 & 3.604 & 34,43 \\
2016 & 1.273 & 1.549 & 3.742 & 34,02 \\
Rata-rata & - & - & - & 34,13 \\
\hline
\end{tabular}

Sumber: BPS Provinsi Jambi, 2017

Berdasarkan tabel 4, realisasi PAD menunjukkan peningkatan, dimana pada tahun 2010 sebesar Rp.686 miliar dan pada tahun 2016 menjadi sebesar Rp. 1.273 miliar atau tumbuh rata-rata sebesar 11,89 persen pertahun. Peningkatan PAD ini belum sepenuhnya dapat diandalkan dalam menopang Anggaran Pendapatan dan Belanja Daerah (APBD) Provinsi Jambi, karena kontribusi PAD terhadap APBD relatif masih rendah bahkan cenderung menurun. Pada tahun 2010, PAD memberikan kontribusi sebesar 37,26 persen, tahun 2011 meningkat menjadi 40,46 persen, dan tahun 2016 PAD hanya mampu memberikan kontribusi terhadap APBD Provinsi Jambi sebesar 34,02 persen. Kondisi ini tentunya menyebabkan masih tingginya kertegantungan dana dari pemerintah pusat. 
Pemerintah Provinsi Jambi dalam usaha untuk membangun daerah dan mengejar pertumbuhan ekonomi yang optimal telah berupaya untuk menggali sumber-sumber keuangan darah agar dapat mengurangi kertegantungan dana dari pemerintah pusat terutama yang bersumber dari pendapatan asli daerah sesuai potensi yang dimilikinya. Upaya tersebut dilakukan dengan intensifikasi dan ekstensifikasi sumber-sumber PAD, agar peningkatan target setiap tahunnya dapat diikuti dengan pencapaian realisasi secara konsisten.

Pemerintah Provinsi Jambi menyadari bahwa Pendapatan Asli Daerah adalah merupakan bagian yang turut menentukan suksesnya pembangunan yang dilaksanakan maka pemerintah mengusahakan agar tidak terjadi lagi penurunan atau minimal mempertahankan nilai yang dicapai sebelumnya dengan jalan peningkatan pengawasan yang intensif dari petugas/aparat yang bersangkutan serta memberikan penyuluhan-penyuluhan kepada masyarakat akan pentingnya Pendapatan Asli Daerah tersebut dalam menunjang pembangunan Daerah.

\section{Laju Pertumbuhan Ekonomi}

Pertumbuhan ekonomi Provinsi Jambi yang digambarkan oleh PDRB atas dasar harga konstan. Selama kurun waktu dari tahun 2010 hingga tahun 2016, pertumbuhan ekonomi Provinsi Jambi rata-rata tumbuh sebesar 6.28 persen pertahun. Secara rinci pertumbuhan ekonomi Provinsi Jambi per masing-masing sektor pada tahun 2010 - 2016 dapat dilihat pada Tabel berikut ini:

Tabel 5. Pertumbuhan Ekonomi Provinsi Jambi Menurut Sektor Ekonomi Tahun 2010 - 2016 (dalam \%)

\begin{tabular}{|c|c|c|c|c|c|c|c|c|}
\hline Kode & Lapangan Usaha & 2010 & 2011 & 2012 & 2013 & 2014 & 2015* & $2016 * *$ \\
\hline A & $\begin{array}{l}\text { Pertanian, Kehutanan, dan } \\
\text { Perikanan }\end{array}$ & - & 4.73 & 6.81 & 6.21 & 11 & 5.22 & 6.59 \\
\hline B & Pertambangan dan Penggalian & - & 12.4 & 4.88 & 3.83 & 4.24 & -0.23 & 0.44 \\
\hline $\mathrm{C}$ & Industri Pengolahan & - & 8.3 & 7.19 & 8.17 & 4.81 & 2.33 & 2.29 \\
\hline $\mathrm{D}$ & Pengadaan Listrik dan Gas & - & 13.3 & 9.67 & 8.73 & 15.3 & 7.48 & 6.16 \\
\hline $\mathrm{E}$ & $\begin{array}{l}\text { Pengadaan Air, Pengelolaan } \\
\text { Sampah,Limbah dan Daur Ulang }\end{array}$ & - & 5.21 & 0.82 & 1.87 & 4.35 & 4.08 & 5.02 \\
\hline $\mathrm{F}$ & $\begin{array}{l}\text { Konstruksi } \\
\text { Perdagangan Besar dan Eceran; }\end{array}$ & - & 5.52 & 17 & 19.5 & 8.92 & 3.33 & 3.54 \\
\hline G & $\begin{array}{l}\text { Reparasi Mobil dan Sepeda } \\
\text { Motor }\end{array}$ & - & 8.34 & 8.86 & 8.22 & 8.8 & 11.02 & 6.27 \\
\hline $\mathrm{H}$ & Transportasi dan Pergudangan & - & 5.81 & 8.42 & 7.88 & 8.18 & 6.59 & 8.29 \\
\hline I & $\begin{array}{l}\text { Penyediaan Akomodasi dan } \\
\text { Makan Minum }\end{array}$ & - & 6.24 & 7.73 & 6.4 & 18.7 & 6.49 & 7.65 \\
\hline $\mathrm{J}$ & Informasi dan Komunikasi & - & 7.32 & 7.36 & 6.53 & 7.01 & 9.83 & 8.51 \\
\hline $\mathrm{K}$ & Jasa Keuangan dan Asuransi & - & 20.8 & 9.98 & 11.8 & 3.84 & 2.11 & 10.38 \\
\hline $\mathrm{L}$ & Real Estat & - & 6.05 & 5.66 & 4.93 & 2.2 & 4.19 & 4.31 \\
\hline $\mathrm{M}, \mathrm{N}$ & Jasa Perusahaan & - & 1.49 & 4.22 & 2.04 & 5 & 6.32 & 5.24 \\
\hline $\mathrm{O}$ & $\begin{array}{l}\text { Administrasi Pemerintahan, } \\
\text { Pertahanan dan Jaminan Sosial } \\
\text { Wajib }\end{array}$ & - & 4.14 & 3.96 & 4.57 & 13.4 & 6.79 & 3.01 \\
\hline $\mathrm{P}$ & Jasa Pendidikan & - & 2.48 & 6.34 & 5.39 & 1.28 & 7.48 & 6.04 \\
\hline Q & $\begin{array}{l}\text { Jasa Kesehatan dan Kegiatan } \\
\text { Sosial }\end{array}$ & - & 3.8 & 8.78 & 8.07 & 15.2 & 10.05 & 6.64 \\
\hline \multirow[t]{2}{*}{$\mathrm{R}, \mathrm{S}, \mathrm{T}, \mathrm{U}$} & Jasa lainnya & - & 3.8 & 3.31 & 4.8 & 5.55 & 8.76 & 6.59 \\
\hline & $\begin{array}{l}\text { Produk Domestik Regional } \\
\text { Bruto }\end{array}$ & - & 7.86 & 7.03 & 6.84 & 7.36 & 4.2 & 4.37 \\
\hline
\end{tabular}

Sumber : BPS Provinsi Jambi, Tahun 2017 
Dilihat dari tabel 5, Laju pertumbuhan ekonomi Provinsi Jambi menunjukkan fluktuatif dan relatif cenderung menurun. Laju pertumbuhan PDRB Jambi tahun 2016 mencapai 4,37 persen, jauh lebih rendah dibandingkan tahun 2011 sebesar 7,68 persen. Seluruh kategori dalam kegiatan ekonomi pada tahun 2016 mencatat pertumbuhan yang positif. Pertumbuhan ekonomi tertinggi dicapai oleh kategori Jasa Keuangan dan Asuransi sebesar 10,38 persen. Adapun kategori-kategori lainnya berturut-turut mencatat pertumbuhan yang positif, di antaranya kategori Informasi dan Komunikasi 8,51 persen; kategori Transportasi dan Pergudangan sebesar 8,29 persen; kategori Penyediaan Akomodasi dan Makan Minum sebesar 7,65 persen; kategori Jasa Kesehatan dan Kegiatan Sosial mencatat sebesar 6,64 persen; pertumbuhan yang sama terjadi pada kategori Pertanian, Kehutanan, dan Perikanan; serta kategori Jasa Lainnya yaitu sebesar 6,59 persen; kategori Perdagangan Besar dan Eceran; Reparasi Mobil dan Sepeda Motor sebesar 6,27 persen; kategori Pengadaan Listrik dan Gas; serta kategori Jasa Pendidikan masing-masing sebesar 6,16 persen dan sebesar 6,04 persen. Untuk kategori lainnya, pertumbuhan berada di bawah 6 persen.

\section{Pengaruh Pengeluaran Pemerintah Terhadap Pertumbuhan Ekonomi}

\section{a. Analisis Regresi Linier}

Setelah memberikan gambaran umum mengenai perkembangan masing-masing variabel yang dimaksud dalam penelitian ini, maka pada bagian ini akan dibahas hasil perhitungan empirik yang telah diolah dengan menggunakan perhitungan regresi melaui bantuan program SPSS Windows V.22. Tujuan dari perhitungan regresi ini adalah untuk mengetahui bagaimana tingkat signifikansi pengaruh antara variabel bebas yaitu Pengeluaran Pemerintah (TBD) terhadap variabel terikat yaitu Pertumbuhan Ekonomi (PDRB Riil) Provinsi Jambi dengan tahun pengamatan 2010-2016. Hasil pengolahan dengan program SPSS Windows V.22, diketahui koefisien regresi sebagaimana pada tabel 6 berikut ini:

\section{Tabel 6}

Nilai Koefisien Regresi dan $\mathbf{t}$ hitung

\begin{tabular}{llrrrrr}
\hline & Model & \multicolumn{2}{c}{ Unstandardized } & \multicolumn{2}{c}{$\begin{array}{c}\text { Standardized } \\
\text { Coefficients }\end{array}$} & \multicolumn{2}{c}{$\begin{array}{c}\text { Coefficients } \\
\text { Beta }\end{array}$} & \multicolumn{1}{c}{ t } & Sig. \\
& \multicolumn{1}{c}{ B } & Std. Error & \multicolumn{1}{c}{ Betar } \\
\hline 1 & (Constant) & 12.895 & .999 & & 12.912 & .000 \\
& TBD & .379 & .067 & .929 & 5.635 & .002 \\
\hline
\end{tabular}

a. Dependent Variable: PE

Berdasarkan tabel diatas, dapat diketahui nilai persamaan regresi linier sederhana sebagai berikut :

$$
\operatorname{Ln} \mathrm{FE}_{\mathrm{t}}=\mathrm{Ln} 12,895+0,379 \operatorname{Ln} \mathrm{TBD}_{\mathrm{t}}
$$

Berdasarkan persamaan regresi tersebut maka dapat dijelaskan bahwa koefisien regresi positif. Hal ini menunjukkan bahwa peningkatan pengeluaran pemerintah untuk kegiatan pembangunan ekonomi daerah mempunyai efek positif terhadap peningkatan pertumbuhan ekonomi di Provinsi Jambi. Nilai koefisien regresi pengeluaran pemerintah sebesar 0,379 , berarti apabila pengeluaran pemerintah mengalami kenaikan sebesar 
1 persen, akan dapat mengakibatkan peningkatan pertumbuhan ekonomi di Provinsi Jambi sebesar 0,379 persen, dengan asumsi variabel lain konstan (ceteris paribus). Nilai Ln $\alpha$ (konstanta) $=12,895$ menunjukkan bahwa apabila tidak terjadi pengalokasian pengeluaran pemerintah akan dapat mengakibatkan pertumbuhan ekonomi atas dasar PDRB riil hanya sebesar 12,895 triliun.

\section{b. Analisis Koefisien Determinasi $\left(\mathbf{R}^{2}\right)$ dan Korelasi $(\mathbf{R})$}

Determinasi merupakan suatu ukuran yang penting dalam regresi, karena dapat menginformasikan baik atau tidaknya model regresi yang terestimasi, atau dengan kata lain angka tersebut dapat mengukur seberapa dekatkah garis regresi yang terestimasi dengan data sesungguhnya. Nilai koefisien determinasi $\left(\mathrm{R}^{2}\right)$ ini mencerminkan seberapa besar variasi dari variabel terikat (dependen) dapat diterangkan oleh variabel bebas (independen).

Pada tabel 4.4, koefisien determinasi $\left(\mathrm{R}^{2}\right)$ menunjukkan suatu model regresi tersebut dapat digunakan untuk mengestimasi variabel yang diteliti. Nilai $\mathrm{R}^{2}=0,864$ menandakan bahwa variasi dari perubahan pertumbuhan ekonomi mampu dijelaskan oleh variasi perubahan pengeluaran pemerintah Provinsi Jambi sebesar 86,4 persen, sedangkan sisanya 13,6 persen dijelaskan oleh faktor-faktor lain yang tidak dibahas dalam model ini.

Tabel 7

Nilai Koefisien Korelasi (R) dan Diterminasi $\left(\mathbf{R}^{\mathbf{2}}\right)$

\begin{tabular}{ccccc}
\hline Model & $\mathrm{R}$ & R Square & $\begin{array}{c}\text { Adjusted R } \\
\text { Square }\end{array}$ & $\begin{array}{c}\text { Std. Error of the } \\
\text { Estimate }\end{array}$ \\
\hline 1 & $.929^{\mathrm{a}}$ & .864 & .837 & .05402289 \\
\hline
\end{tabular}

a. Predictors: (Constant), TBD

b. Dependent Variable: PE

Koefisien korelasi digunakan untuk mengukur kuat lemahnya hubungan antara variabel bebas (independen) dan variabel terikat (dependen). Pada tabel 7 diketahui nilai koefisien korelasi $(\mathrm{R})=0.929$ berarti bahwa tingkat korelasi antara variabel pengeluaran pemerintah terhadap variabel pertumbuhan ekonomi Provinsi Jambi adalah sangat kuat dan arahnya positif. Hal ini ditandai dengan nilai $\mathrm{R}$ yang semakin mendekati 1 .

\section{Pengujian Hipotesis}

Setelah mengetahui hubungan antara masing-masing variabel, maka selanjutnya akan dilakukan uji $\mathrm{t}$ untuk mengetahui tingkat signifikansi pengaruh antara variabel bebas terhadap variabel terikat. Caranya adalah dengan membandingkan antara nilai thitung dengan tabel. Apabila thitung lebih besar dari ttabel (thitung > tabel), maka pengaruhnya adalah signifikan. Kalau yang terjadi adalah sebaliknya yaitu thitung lebih kecil dari ttabel (thitung $<$ tabel), maka pengaruh antara variabel tersebut tidak signifikan.

Berdasarkan tabel 4.3 diketahui nilai thitung untuk variabel pengeluaran pemerintah sebesar 5,635. Untuk tabel dengan $\mathrm{df}=5$ pada tingkat signifikansi alpha 5\% $(\alpha=0,05)$ dengan tingkat keyakinan $95 \%$ diperoleh 
nilai sebesar 2,57058. Hasil ini menunjukkan bahwa nilai thitung lebih besar dari nilai tabel (thitung $>$ tabel). Hal ini berarti variabel pengeluaran pemerintah berpengaruh signifikan terhadap pertumbuhan ekonomi di Provinsi Jambi.

\section{simpulan}

\section{SIMPULAN DAN SARAN}

Berdasarkan pembahasan yang telah dilakukan, maka dapat ditarik suatu kesimpulan sebagai berikut :

1. Kemampuan keuangan daerah yang dilihat dari perbandingan realisasi Pendapatan Asli Daerah dengan Total Belanja Daerah pada APBD Provinsi Jambi selama periode 2010-2016 walau relatif rendah namun telah menunjukkan peningkatan dimana rata-rata peningkatan mencapai 34,13 persen pertahun.

2. Laju pertumbuhan ekonomi Provinsi Jambi yang digambarkan melalui PDRB atas harga konstan (PDRB Riil) menunjukkan trend yang fluktuatif dan cenderung menurun. Selama periode 2010-2016 rata-rata pertumbuhan sebesar 6,28 persen per tahun.

3. Pengeluaran Pemerintah berpengaruh secara signifikan dan positif terhadap Pertumbuhan Ekonomi Provinsi Jambi.

\section{Saran}

1. Penerimaan daerah yang meningkat terutama PAD akan dapat menunjang dari penyediaan dana untuk pembangunan dan pelayanan publik. Pada APBD Provinsi Jambi, sumbangan PAD terhadap APBD masih rendah, maka diperlukan kerja keras pemerintah Provinsi Jambi untuk meningkatkan realisasi penerimaan PAD, dengan cara melibatkan semua staholder yang ada di daerah untuk mencari solusi bersama dalam menggali sumber-sumber potensi PAD yang ada, dilakukan secara konsisten dan proposional sesuai dengan peraturan perundangan yang ada.

2. Pertumbuhan Ekonomi merupakan cerminan keberhasilan pemerintah dalam meningkatan kesejahteraan masyarakat. Untuk itu, pemerintah Provinsi Jambi harus terus mendorong kegiatan ekonomi masyarakat pada semua sektor ekonomi, baik dari sesi regulasi peraturan daerah maupun penyediaan sarana dan prsarana pendukung yang lebih baik.

\section{DAFTAR PUSTAKA}

Arsyad, Lincolin, 1999, Pengantar Perencanaan dan Pembangun-an Ekonomi Daerah, Edisi Pertama, BPFE, Yogyakarta.

Badan Pusat Statistik, 2016. Laju Pertumbuhan Ekonomi Menurut Provinsi seSumatera 2005-2015. (Dalam Persen) Jambi.

--------, 2016. Statistik Keuangan Daerah Provinsi Jambi 2016. BPS Jambi.

--------, 2017, Propinsi Jambi dalam Angka tahun 2016. BPS Jambi.

Bappeda Provinsi Jambi. 2016, Realisasi Belanja Daerah Tahun 2010 - 2016, Jambi.

Dumairy. 1996. Perekonomian Indonesia. Jakarta: Erlangga.

Ghozali, Imam. 2011. Analisis Multivariate Lanjutan dengan Program SPSS. Semarang : Badan Penerbit Universitas Diponegoro. 
Hidayat, Paidi dan Sirojuzilan. 2006. Kajian Tentang Keuangan Daerah Kota Medan Era Otonomi Daerah Periode 2001-2005. Jurnal Perencanaan dan pengembangan Wilayah,Vol 2, No.1 Agustus 2006.

Jhinghan, ML. 2002. Ekonomi Pembangunan dan Perencanaan. PT. Raja Grafindo Persada. Jakarta.

Mangkoesoebroto, Guritno, 2008. Ekonomi Publik. Edisi 3. BPFE, Yogyakarta.

Mankiw, N. Gregory. 2007. Macroeconomics. New York: Worth Publishers.

Peraturan Pemerintah No. 105 Tahun 2000 tentang Pertanggungjawaban Pengelolaan Keuangan Daerah.

Peraturan Pemerintah No. 58 Tahun 2008 tentang Pengelolaan Keuangan Daerah.

Peraturan Menteri Dalam Negeri No. 52 tahun 2015 tentang Pedoman Pengelolaan Keuangan Daerah.

Prasetyo, P. Eko. 2009. Fundamental Makro Ekonomi, Beta Offset, Yogyakarta.

Sodik, J. 2007. Pengeluaran Pemerintah dan Pertumbuhan Ekonomi Regional: Studi Kasus Data Panel Di Indonesia. Vol. 12 Nomor 1. Economic Journal of Emerging Markets.

Sugiyono, 2011. Metode Penelitian Kuantitatif dan Kualitatif dan $R \& D$, Alfabeta, Bandung.

Sukirno, Sadono. 2008. Makroekonomi Modern, Perkembangan Pemikiran dari Klasik Hingga Keynesian Baru. PT. Raja Grafindo Persada. Jakarta.

--------, 2013. Pengantar Teori Makroekonomi. PT. Raja Grafindo Persada. Jakarta.

Suryono, Agus. 2010. Dimensi-dimensi Prima Teori Pembangunan. Malang: UB Press.

Tambunan, Tulus. 2001. Perekonomian Indonesia: Teori dan Temuan Empiris. Jakarta: Ghalia Indonesia.

Todaro, Michael P. 2000. Pembangunan Ekonomi di Dunia Ketiga. Jilid I \& II. Terjemahan. Jakarta: Erlangga.

Todaro, M.P. dan S.C. Smith. 2006. Pembangunan Ekonomi di Dunia Ketiga.. Edisi ke Sembilan. Jakarta: Erlangga.

Undang-Undang Nomor 57 Tahun 1957 tentang Pembentukan Daerah Tingkat I Sumatera Barat, Jambi dan Riau.

Undang-Undang Nomor 23 Tahun 20014 tentang Pemerintahan Daerah.

Widarjono, Agus. 2005. Ekonometrika, Ekonosia, Yogyakarta. 